\title{
Ecotourism in the North Pantanal, Brazil: Regional Bases and Subjects for Sustainable Development
}

\author{
MARUYAMA Hiroaki*, NIHEI Takaaki**, and NISHIWAKI Yasuyuki* \\ *Faculty of Education and Human Sciences, Yokohama National University, \\ Yokohama 240-8501, Japan \\ **Graduate School of Life and Environmental Sciences, University of Tsukuba, \\ Tsukuba, Ibaraki 305-8572, Japan
}

\begin{abstract}
The Brazilian Pantanal, the world's largest wetland holding abundant wildlife, has recently drawn profound concern about the development of the tourist industry. To provide significant proposals for ecotourism in the wetland, we believe that detailed data acquired by fieldwork is requisite. This study examines the regional bases that carry regional ecotourism, and attempts to present some proposals for ecotourism from the case of the north Pantanal. The results are shown as follows in order of regional scale. (1) In the water source of the Pantanal, Cerrado region, it is necessary to make efficient plans to control recent agricultural development, especially in soybean and cotton production. (2) On the wetland level, legally protected areas such as national parks and RPPN (Reserva Particular do Patrimônio Natural) should be extended. (3) On the municipal level, environmental subsidies are needed for disused goldmines, and for the maintenance of tourist infrastructures such as Transpantaneira and MT 370. (4) Modern hotels and eco-lodges need to provide ecotourism organized by local people, and to equip the facilities with adequate sewage facilities and garbage recycle plants to preserve the natural environment.
\end{abstract}

Key words: ecotourism, Transpantaneira, hotel, eco-lodge, Pantanal, Brazil

\section{Introduction}

The expansion of mass-tourism involving not only developed countries but also developing countries has reached terrestrial scale. At the same time, the problems that mass-tourism causes are apparent, such as the disturbance of natural resources, indigenous culture and society. This situation is essentially a result of the development of tourism that pursues a highreturn in the short term. In such conditions, alternative tourism was conceived, and the notion of ecotourism was manifested in the late 1980s (Ceballos-Lascurain 1987; Weaver 1998).

Though the definition of ecotourism varies among researchers, it consists of natureadventure-culture oriented travel such as wildlife-watching, adventure travel, cultural and historical travel (The International Ecotourism Society 2000). Ecotourism is basically a concept to bring fruition to sustainable develop- ment $^{1}$ that aims at coping with the fixation and indivisible quandaries of tourism in the late 1980s (Funck 2002). That is to say, ecotourism entails the practice of "sustainable tourism," or "responsible tourism," which gives priority to regional resources and residents (Lindberg and Hawkins 1993; Fennell 1999). However, from the beginning it holds a contradiction in economic development and environmental preservation.

With the participation and cooperation of regional people, ecotourism achieves environmental preservation in the tourism sector that accompanies sustainable usage of regional nature and culture resources. It is certainly different from "external tourism" that is brought frequently by profit-seeking developers from outside the region, and is an attempt to conceive self-supportable "internal tourism." The initiative should be substantiated by the people in the region in which ecotourism is practiced, and it follows an understanding of long-lasting 
preservation and protection of the resources of tourism (Ishimori 2001; Foucat 2002).

In order to practice the principles of ecotourism, it is necessary that scrupulous guidelines should be created for every place in terms of regional conditions of natural and social resources. Then, ecotours of as high quality as commercial tours should be offered to tourists (Ross and Wall 1999). The guidelines must include the purposes of the tour, actual practice methods, and codes of conduct. This also relates to people who are indirectly connected with ecotourism. It should simultaneously provide tourists with environmental and humanistic education (Japan Ecotourism Society 1999; Ceballos-Lascurain 1996).

Actually, superficial ecotours in which amateur travel agencies or guides merely take tourists into the countryside are rampant. This condition contains the possibilities for ecotourism to deteriorate into mass-tourism. Introduction of ecotourism may actually lead to the ironic situation that would bring about the regional destruction of natural, cultural, and social resources, which form the bases of the development of ecotourism (Burton 1998; Weaver 1999). Whereas great anticipation and concern is given to the development of ecotourism, there is also considerable anxiety.

To cope with these problems that ecotourism embraces, the authors believe that it is important to pay attention to the importance of basic data obtained from fieldwork. Former studies on ecotourism are concentrated rather too much in conceptual approaches and inductive theories, and nor seem the information of case studies do not seen sufficient to substantiate the theories. To make persuasive suggestions and to provide considerable data for future ecotourism, this study examines the regional bases that sustain modern ecotourism in the case of the Brazilian Pantanal.

Expanding across the middle part of the South American Continent, the Pantanal is known as the world's biggest wetland. It includes the borders of Brazil, Bolivia and Paraguay, and the total area consists of numerous subdivided wetlands that amount to about 230 thousand square kilometers, which is equal to Honshu island of Japan. In order to preserve the valuable natural environment and biological diversity, UNESCO registered the Pantanal as a World Natural Heritage in 2000. Furthermore, as the environmental problem of the Pantanal extends as a worldwide issue, it has received attention from international organizations such as the World Bank and the InterAmerican Development Bank, WWF, and NGOs.

The empirical data of this study was obtained from our field work conducted mainly in 2001, i.e., interviews with owners and employees of hotels and farms, and government agencies such as EMBRAPA (Empresa Brasileira de Pesquisa Agropecuária), SEMA (Secretaria de Estado de Meio Ambiente), IBGE (Instituto Brasileiro de Geografia e Estatística), IBAMA (Instituto Brasileiro do Meio Ambiente e dos Recursos Naturais Renováveis), and FEMA (Funda, cao Estadual do Meio Ambiente). We also used GPS and GIS to show the location of buildings and trees in large-scale maps.

\section{Study Area}

\section{Centers of Ecotour and the Pantanal}

As in the case of Costa Rica and Ecuador, which are regarded as models of world ecotourism, many regions suitable for ecotourism that enclose abundant nature resources are dispersed in the Central and South Americas. Regions such as the Amazon, the Andes, the Galapagos, and Patagonia, are popular as ecotour tourists can enjoy nature fully (Sendai 2001; Duffy 2002; Wallace and Pierce 1996). In the case of Brazil, EMBRATUR (Empresa Brasileira de Turismo, Instituto Brasileiro de Turismo) designated 26 centers of ecotourism (pólo de ecoturismo) in order to introduce ideal regions for ecotourism to domestic and foreign tourists. The main cause of the designation by the governmental organization can be attributed to the rise of the ecotourism in the Pantanal and Amazonas in the late 1980s and early 1990s.

The centers of ecotour are roughly divided into four regions, i.e., Amazon (numbers of the centers of ecotours: 1), Pantanal (3), North East (13), and South East (9) as shown in Figure 1. Except for the Amazon and the Pantanal, the 


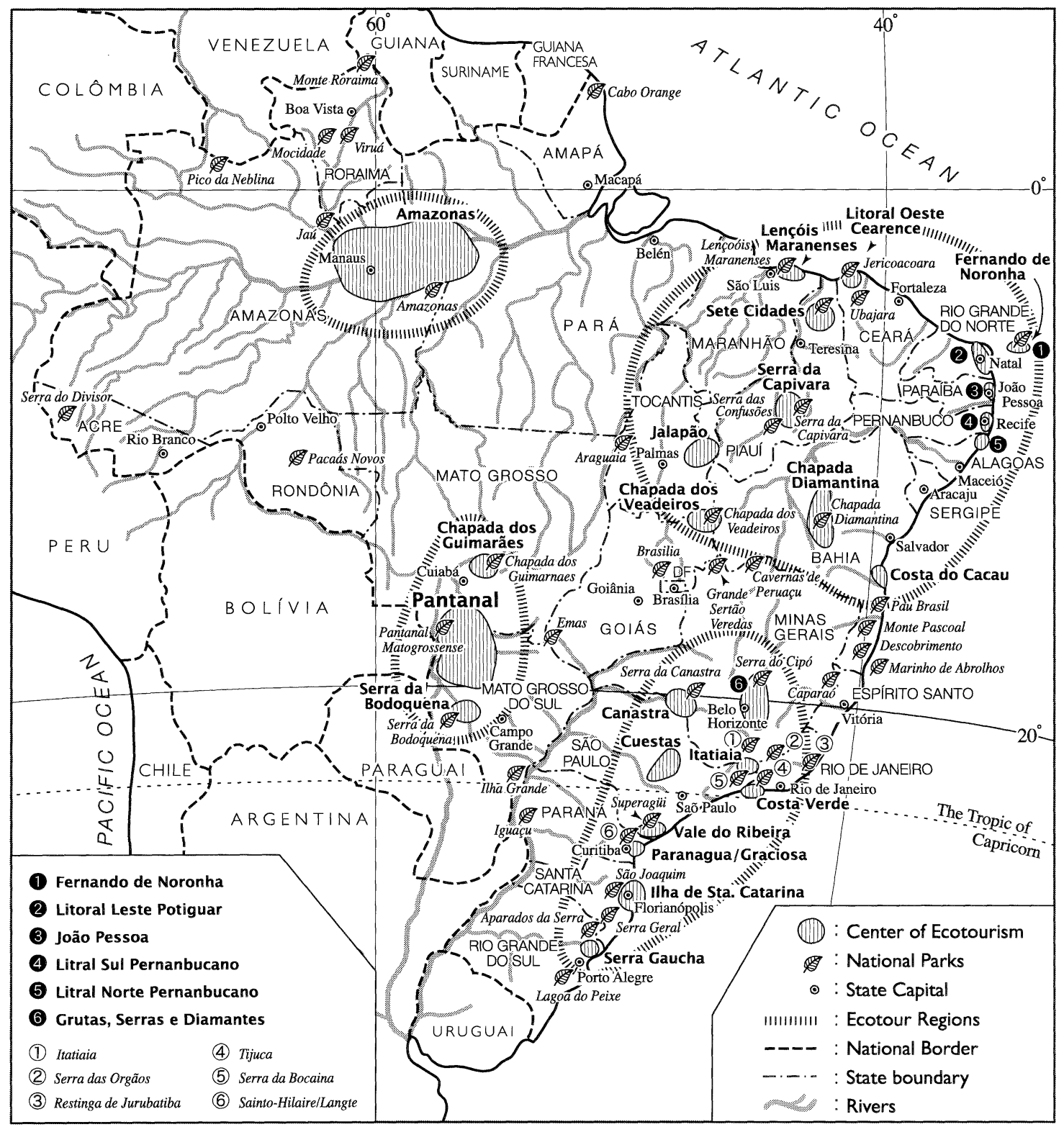

Figure 1. Centers of ecotourism and national parks in Brazil, 2003. Source: EMBRATUR

area of the centers of ecotours in the plateau and coastal region is minute. Almost all of the ecotour centers are located in and around national parks. The Parque Nacional do Pantanal Mato-grossense is the only national park located in the Pantanal. It was designated as a national park on the 24th of September 1981, seven years after the Amazonas, and the area, 135 thousand ha, is the fifteenth largest among the 47 national parks in Brazil. ${ }^{2}$ Comparing with the large area of the center of ecotourism in the Pantanal, the area of national park protected by government is small.

\section{Nature in and around the wetland}

The wetland of the Pantanal counts for no less than 138 thousand square kilometers of Brazilian territory. The great wetland is sur- 


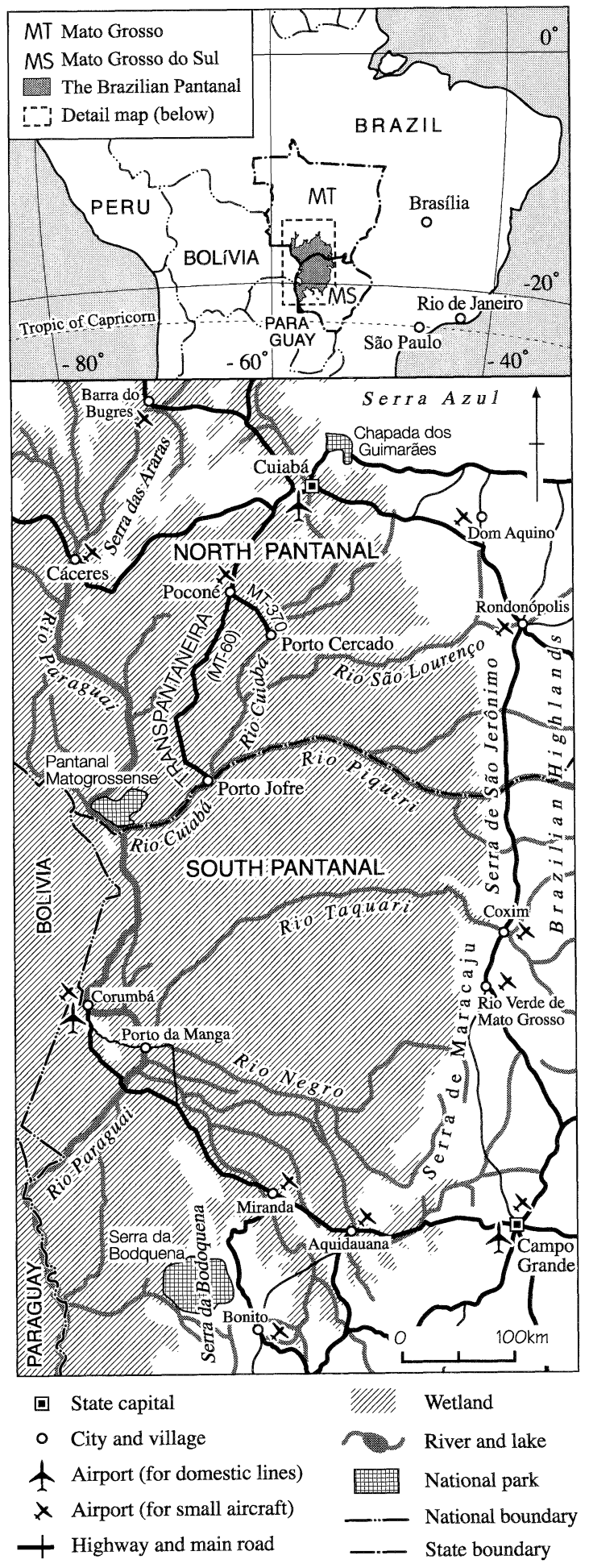

Figure 2. Location of the north Pantanal. rounded by the extensive Brazilian Plateau in the east, the Gran Chaco of Bolivian territory in the west, and the Paresis Mountains that form the watershed between the Amazon and the Paraguay River (Figure 2). Climatically, belonging to the savanna, the average annual temperature is as high as $24^{\circ} \mathrm{C}$. The yearly precipitation is around $1100 \mathrm{~mm}$, and it receives $45 \%$ of its rainfall in three months, from December to February.

Described as a wildlife treasury, the Pantanal has abundant flora and fauna. The outlined number of species is 95 mammals, 162 reptiles, 656 birds, 263 fishes and 1700 phanerogams (Ministéroio do Meio Ambiente, dos Recursos Hídricos e da Amazônia Legal 1997; Britski et al. 1999). Typical animals are the jacaré (caiman) and the capivara whose population is assumed to be $3.5-10$ million and 0.5 million, respectively (Mourão et al. 2000). Tuiuiu (jabiru: Jabiru mycteria), which is $1.5 \mathrm{~m}$ in height and has a $2.6 \mathrm{~m}$ of wing, is regarded as the symbol of the Pantanal. In addition to these animals, there is a large number of endangered species documented in Washington Treaty Appendix I, such as the cervo campo (marsh deer: Blastocerus dichtomus) and the arara azul (hyacinth macaw: Anodorhynchus hyacinthinus) which also inhabit the wetland (Nakasumi 1990).

The flora of the plateaus and plains around the wetland is called Cerrado. It consists mainly of shrubs and bush trees. ${ }^{3}$ The Cerrado region is also regarded as one of the most prolific wildlife reserves in the world, as it is called "hot-spot of wildlife." Regarded as the feed tank of the wetland, the precipitation of the Cerrado region in the east of the Pantanal amounts to $1600 \mathrm{~mm}$ per year (Swarts 2000). Recently, agricultural development focusing on the production of soybean and cotton has rapidly grown in the Cerrado region. In addition, the Hydrovia Plan, that aims to construct a large waterway crossing the wetland in order to export the yields of the region, was underway (Trent 2000). It is necessary to pay sufficient attention to the future development of the plan since it might fundamentally change the ecosystem of the wetland and prompt the further development of the Cerrado region. 


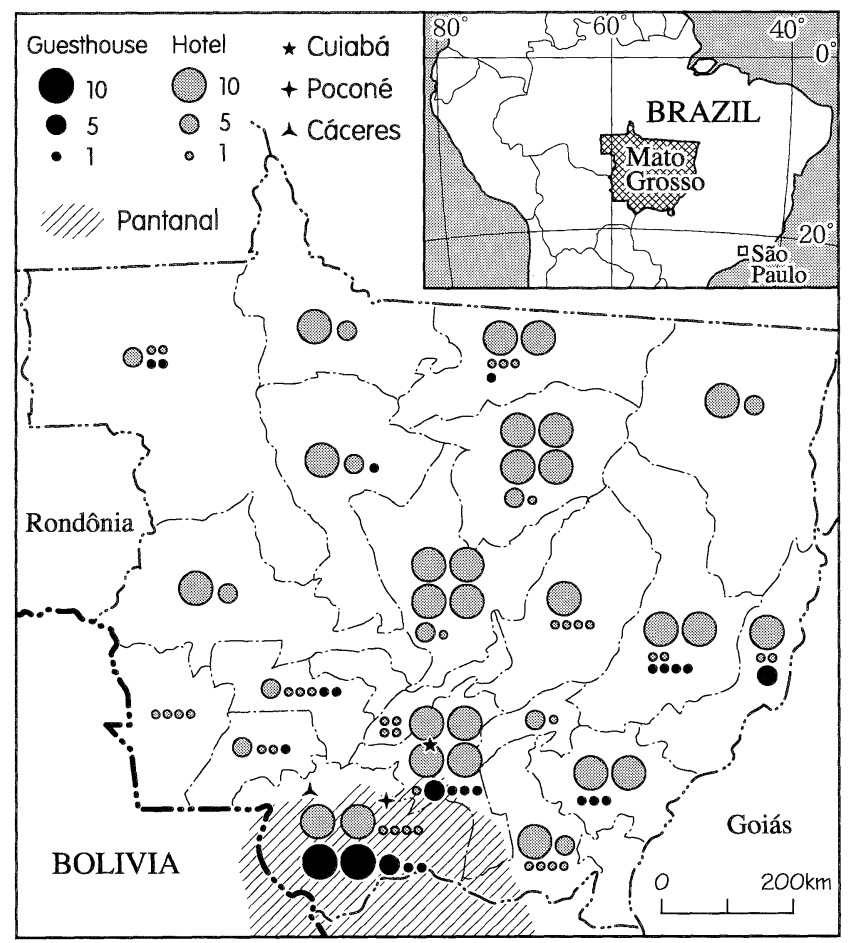

Figure 3. Distribution of accommodations in Mato Grosso, 2001.

Source: Secretaria de Estado de Planejamento e Coordenação Geral, Governo de Mato Grosso

\section{The north Pantanal}

Concerning the name values of ecotourism especially among sightseers from foreign countries, the north Pantanal (Pantanal Norte) located in the state of Mato Grosso, can be considered the center of ecotourism in the Brazilian Pantanal. ${ }^{4}$ The capital city of the state, Cuiabá, has became an important base for the regional ecotourism (Bordest et al. 1996). Not only is it close to the wetland, but the city also provides many kinds of services indispensable for the development of ecotourism, such as hotels, travel agencies, and transportation companies including bus, taxi and rental car companies. The package-tour of the Chapada dos Guimarães, which is known for its odd-shaped buttes and mesas is one of them.

The differences in the provision of infrastructures such as accommodation (hotels and lodges) and the scenic roads that are symbolized by Transpantaneira (Rodovia Transpantaneira) resulted in the divergence of the development of tourism between the north and the south (Nihei 2003). The location of accommodation in north Pantanal, such as hotels and lodgings (pousadas), is concentrated in two counties (microregiões), i.e., Cuíaba and Poconé. In the Cuiabá county, which consists of five cities (municípios) including the state capital, there are 49 places of accommodation available (Figure 3). There are 27 lodgings in the Alto Pantanal County. Most of the lodgings are eco-lodges designated for ecotourists. The municipal also includes the gate towns to the wetland, i.e., Cáceres, Poconé and Barão de Melgaço.

\section{Ecotourism at the Municipal Scale}

\section{Gate towns}

Cáceres and Poconé are gateways to the wetland through overland routes. Cáceres is a town with a population of 73,596 , which spreads all the way to the levee of the Paraguay River. The town is located $215 \mathrm{~km}$ west of Cuiabá, following national Highway 70. Barely $90 \mathrm{~km}$ from the town is San Matias, the border 
town of Bolivia which is known as a free trade zone and so is exempt from taxation. Ecolodges and fishing inns are established along the Paraguay River near the city of Cáceres. Locals offer sightseeing on the rivers and sports fishing by small motorboats and vessels with lodging facilities (chalana). South of the Paraguay River is the Estação Ecológica Taiamã, which is one of the rare environmental observation points in the Pantanal.

Cáceres is famous for its international fishing festival (FIP: Festival Internacional de Pesca) mentioned as the world's largest boat fishing competition in fresh water by the Guinness Book of Records. More than 2000 fishers not only from Brazil but also from all over the world compete at the festival held every September, and a great number of tourists also visit and enjoy cultural events such as traditional dances, music concerts, and handicraft markets (SEDTUR 2001). In the festival no less than 400 boats launch from the competition platform to pursue large-sized fish, i.e. pintado (Pseudoplatystoma corruscans), surubim (Pseudoplatytoma fasciatum), piraputanga (Brycon microlepis), while children and teenagers drop fishing lines from the riverside. ${ }^{5}$ Education campaigns to train fishing guides are also run during the competition.

Located $182 \mathrm{~km}$ east of Cáceres, and just 100 $\mathrm{km}$ south of Cuiabá along state Highway 60, Poconé is also an important tourist town in the north Pantanal. The municipality holds a population of 29,970 in an area of $17,126 \mathrm{~km}^{2}$. While the ecotourism of Cáceres, which faces the Paraguai River, specializes in fishing, the observation of wildlife and plants is prevalent in Poconé. The town was deforested in 1777 when a gold mine was found there, and it was named after the native American Beripoconé race.

The town of Poconé is a starting point for passenger transportation to the innermost wetland through the renowned Transpantaneira and state Highway 370. Going southward, Transpantaneira and the state highway terminate respectively in Porto Jofre and Porto Cercado. Both of the villages face the Cuiabá River. Travel agencies in large cities such as Cuiabá have recently started to plan ecotours that capitalize on the abundant wildlife in the wetland and fish in the Cuiabá River. They provide nature observations such as bird watching and sports fishing combined with sightseeing boats in Porto Cercado, and the thrilling adventure of deep wetland crossing over the wooden bridges of the Transpantaneira. These tours are offered especially in the state roads and the halfway stop of the Transpantaneira as a one-day trip (approximately 10 hours) from Cuiabá.

Poconé is known as a historic town, and the traditional festivals held there every year are other resources of tourism. The festivals are unique in the sense that they hand down the cultural fusion of native America, Portugal and Spain, for example, a masked ball (dança dos mascarados) held in May and a tournament (cavalhada) held in July that imitates the fight between the Christians and the Moors. An important consideration is how the cultural heritage of the Pantanal can be incorporated into regional ecotourism, which shows a tendency to the consistent pursuit of nature tourism.

The production of gold is another feature of Poconé. According to the data of SEPLAN (Secretaria de Estado de Planejamento e Coordenação Geral), the municipality produced 2.1 tons of gold, about $47 \%$ of the total gold production in Mato Grosso, in 1999. Around the built-up area of Poconé, there are about 130 gold mines and approximately 5000 gold miners (garimpeiros). Large-scale gold mines are located in the west of the built-up area, where strip mining by large excavators is conducted, and abandoned gold mines are scattering around them. At one abandoned gold mine, vegetation cover did not recover until six years after it closed in 1995. Bare topsoil was left, and water with a large quantity of melted red soil accumulated at the bottom of the deep mining shaft. Gold mine developers have a duty to help the vegetation recover after the mining is ended; however, there is almost no such recognition among them since they regard profit as a priority. Mr. M, living near to the abandoned gold mine, has attempted to reforest by himself for three years. He has planted trees such as pindaiba (Xylopia emarginata) and acuri (Attalea phalerata) and uses the accumulated water in the mining shaft as irrigation. There is no remuneration for his private activity. 


\section{Transpantaneira}

Construction The construction of Transpantaneira that leads deep into the wetland is one of the bases of rapid development of ecotourism in the north Pantanal. In order to promote the stock-farming of the Pantanal by improving shipment, a road was planned in 1970 under the military government. As the name shows, at the beginning, Transpantaneira was intended as an extensive road construction plan to connect Poconé in Mato Grosso and Corumbá in Mato Grosso do Sul.

The road construction began in 1971 from the two towns toward the interior of the wetland, but, it was hard going installing a permanent road in the year-round submerged wetland. Especially in the case of the southern Pantanal, which has the lowest altitude in the wetland, construction workers faced a difficult situation when it was flooded and destroyed by a torrential downpour in 1974. After this, the route from Corumbá was discontinued.

Road construction in the north Pantanal, on the contrary, progressed favorably because the flooding area is relatively limited in comparison with the southern Pantanal. In 1978, it reached completion as scheduled in Porto Jofre, the border of Mato Grosso and Mato Grosso do Sul along the Cuiabá River. The construction of the road that aimed at year-round usage faced problems with water in the rainy season. The Latosol carried from Poconé was piled up on the road, and a long-continued levee-like road appeared. Waterways were built across the road especially at points where a lot of water collected in the rainy season. The wooden bridges built over the points are the feature of the landscape of Transpantaneira.

For ecotourism In the 1980s, the decline of stock-farming in the north Pantanal resulted in the perfunctory maintenance and management of Transpantaneira. The decline of the beef market which was based on extensive grazing and producing of calves damaged the stockfarming of the Pantanal, and the Transpantaneira barely carried out its original function of being a method of shipping cattle. However, after ecotourism was introduced in the late 1980s and developed in the Pantanal, Trans- pantaneira came to hold the important function of being the passenger transportation route of ecotours so that tourists could observe diverse wildlife.

At present, Transpantaneira is an unpaved $147 \mathrm{~km}$ road that links Poconé with Porto Jofre. The gate of Transpantaneira, which is often printed in travel brochures, is located $15 \mathrm{~km}$ south of the built-up area of Poconé (Figure 4). There is an office of IBAMA at the side of the gate, and a signboard that warns tourists not to build fires (Photo 1).

The number of bridges increases as one travels southward, especially in the southern area between Pixaim and Porto Jofre, where there are 85 bridges, which account for $72 \%$ of the bridges. ${ }^{6}$ Tourists who visit the area cross a bridge on average every kilometer. The width of the wooden bridges is about four meters. In the center of the bridges, wooden boards are nailed in two parallel lines to suit the wheel track. The height of wooden bridges from the swamp is approximately two meters. In the dry season, automobiles sometimes take shortcuts through dry fields in order to save time.

Transpantaneira was designated as a park road (estrada parque) by the Federal Government in 1996. Preserved by IBAMA, the natural and cultural resources of the park road are to be used for study and education. For instance, tourists have to stop and pay an entrance fee per car at the office of IBAMA in front of the gate to support the program. Fishers have to receive inspection for the weight of their hauls in the office.

State Highway 370 is also famous as the road of ecotourism in the north Pantanal. The unpaved road connects Poconé and Porto Cercado over $40 \mathrm{~km}$. State Highway 370 was also designated as a park road in 2000, and IBAMA began to practice the services that were directed to sustainable development of regional tourism and the preservation of the ecosystem. The traffic signs that call drivers' attention to the road in order not to hit reptiles are part of this operation (Photo 2).

\section{Eco-lodges and Hotels}

Since the late 1980s, ecotourism has been developed in Brazil, and many tourists, even 


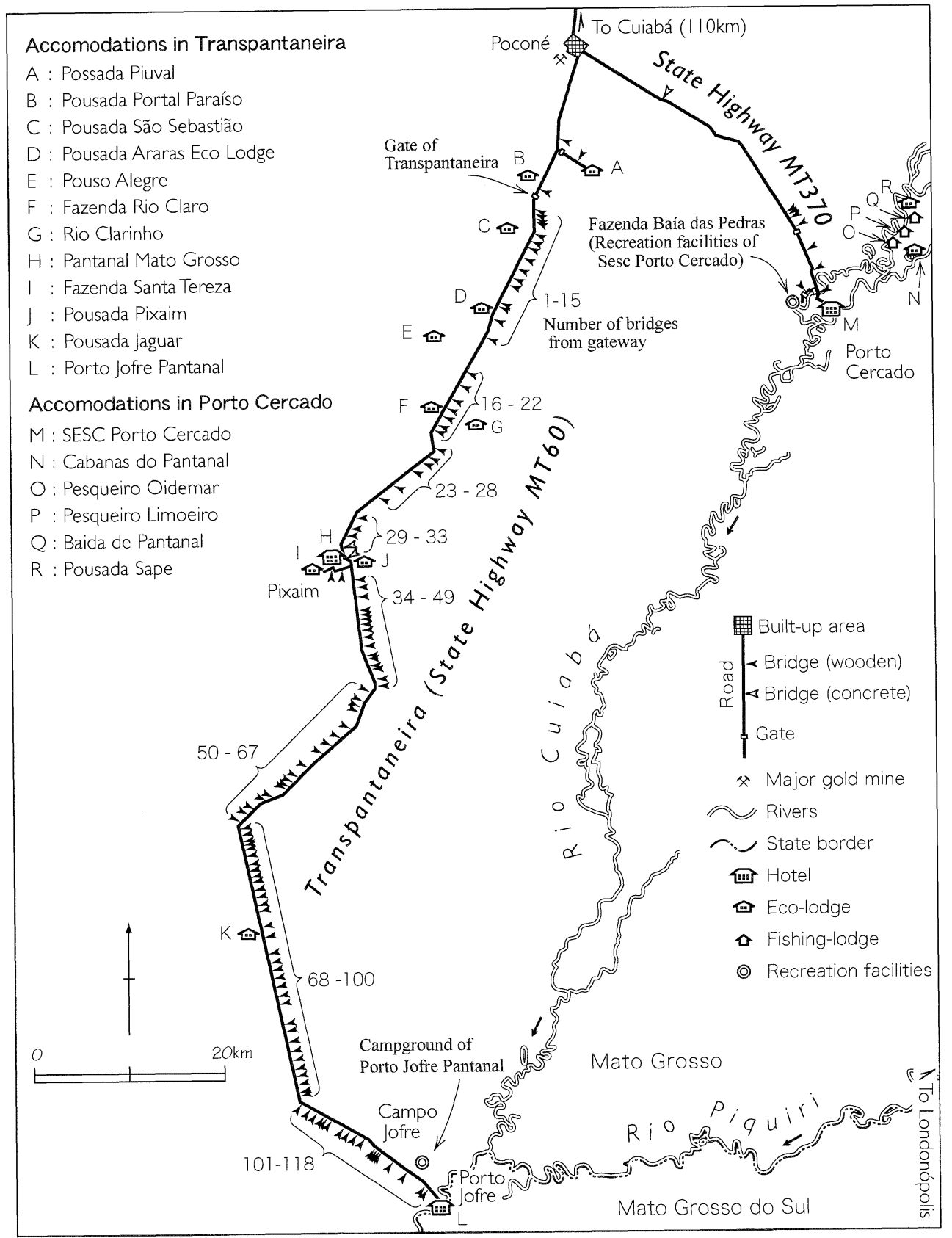

Figure 4. Distribution of accommodations and bridges in Transpantaneira, 2001. Source: Authors' field survey using GPS

from abroad, come to stay in the wetland to enjoy nature, and the management of large ranches (fazenda) along the scenic road has changed dramatically. If a tourist stays two nights, the profit is equivalent to selling two calves. Since ecotourism brings high profit in the short term as compared with farming, owners of ranches scaled down or forsook this sector and tried to earn their living from ecotourism.

The owners of ranches near to Transpantaneira built annexes or extended main houses, 


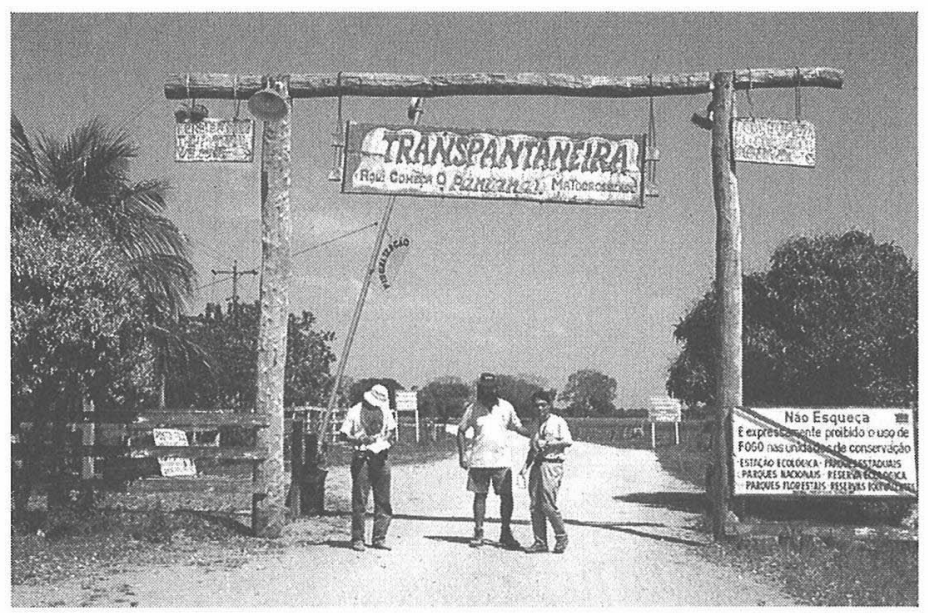

Photo 1. Gate of Transpantaneira (15 Aug. 2001)

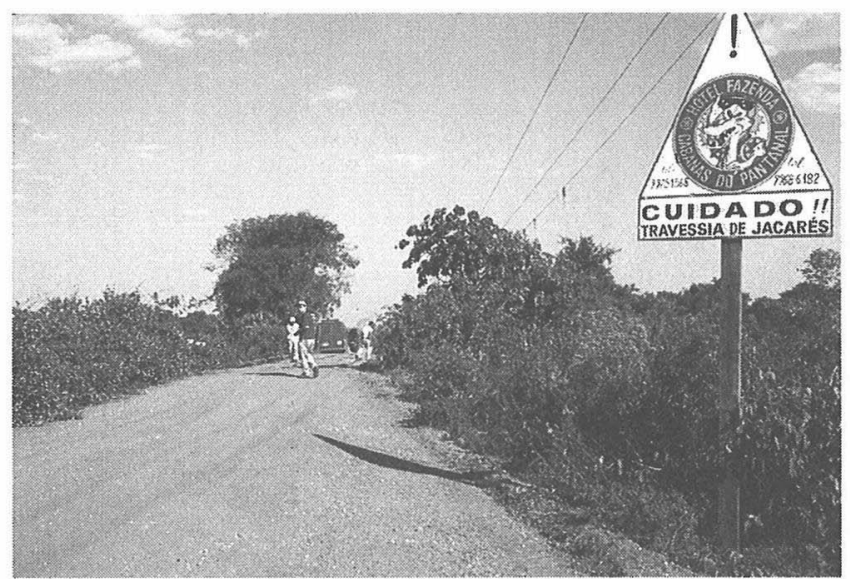

Photo 2. State Highway 370 and a road sign (16 Aug. 2001)

and began to invite tourists in the late 1980s and 1990s. As a result, the eco-lodges utilized the facilities of the ranch, and a bucolic atmosphere for tourism was built, and simple farm house accommodation called pousada or hotel fazenda were constructed (Table 1 and Figure 4). In addition, fishing lodges for sports fishers were built along the Cuiabá River in Porto Cercado, and modern resort hotels such as the Porto Jofre Pantanal and the SESC (Serviço Social de Comércio) Porto Cercado that were equipped with even an larger airport and recreation facilities were developed at the riverbanks.

Most of the accommodation is located along Transpantaneira. There are nine eco-lodges and two hotels. Among them, nine accommoda- tions (eight eco-lodges and one hotel) are located in the north of Pixaim, the northern half of Transpantaneira. The area corresponds with an electrification zone in the wetland $(65 \mathrm{~km}$ south from Poconé). On the other hand, just one eco-lodge and one hotel are located in the south of Pixaim. The hotel Porto Jofre Pantanal is a modern resort hotel that represents the accommodations in the north Pantanal (Nihei 2003). In Campo Jofre, which is deemed a treasury of wildlife, there is a campground (Camping Porto Jofre) managed by the hotel.

Along state Highway 370, a modern hotel SESC Porto Cercado is located just at the end of the path. The Fazenda Baía das Pedras near to the south end of the road is one of recreation facilities of SESC Porto Cercado. The hotel also 
Table 1. Starting year and number of rooms at accommodations in Poconé

\begin{tabular}{|c|c|c|c|c|c|c|}
\hline $\begin{array}{l}\text { Legend } \\
\text { in } \\
\text { Figure } 4\end{array}$ & $\begin{array}{l}\text { Starting } \\
\text { Year }\end{array}$ & Accommodations & $\begin{array}{l}\text { Distance } \\
\text { from } \\
\text { Poconé } \\
(\mathrm{km})\end{array}$ & $\begin{array}{l}\text { Number } \\
\text { of } \\
\text { Rooms }\end{array}$ & $\begin{array}{l}\text { Room } \\
\text { Charge } \\
(\mathrm{R} \$)\end{array}$ & Main Tour and Facilities \\
\hline $\mathrm{J}$ & 1981 & Pousada Pixaim & 67 & 8 & $50-90$ & Horse Riding, Boat \\
\hline $\mathrm{H}$ & 1988 & Pantanal Mato Grosso & 66 & 36 & $136-200$ & $\begin{array}{l}\text { Swimming Pool, Night Bar, Table } \\
\text { Games, Football Ground, Horse } \\
\text { Riding, Boat }\end{array}$ \\
\hline K & 1988 & Pousada Jaguar & 110 & 6 & $160-320$ & Jeep, Boat \\
\hline A & 1989 & Pousada Piuval & 14 & 16 & $80-110$ & $\begin{array}{l}\text { Jeep, Football Ground, Horse } \\
\text { Riding, Fishing, Boat }\end{array}$ \\
\hline $\mathrm{E}$ & 1989 & Pouso Alegre & 40 & 7 & $90-100$ & Horse Riding, Fishing, Boat \\
\hline C & 1990 & Pousada São Sebastião & 35 & 20 & $80-140$ & Boat \\
\hline F & 1990 & Fazenda Rio Claro & 44 & 8 & $50-100$ & Jeep, Horse Riding, Fishing, Boat \\
\hline $\mathrm{L}$ & 1992 & Porto Jofre Pantanal & 147 & 23 & $151-256$ & $\begin{array}{l}\text { Jeep, Campground, Swimming Pool, } \\
\text { Night Bar, Table Games, Fishing, } \\
\text { Boat }\end{array}$ \\
\hline D & 1993 & Pousada Araras Eco Lodge & 33 & 15 & $90-180$ & $\begin{array}{l}\text { Jeep, Swiming Pool, Night Bar, } \\
\text { Horse Riding, Fishing, Boat }\end{array}$ \\
\hline $\mathrm{N}$ & 1995 & Cabanas do Pantanal & 42 & 18 & $90-100$ & Swimming Pool, Horse Riding, Boat \\
\hline B & 1997 & Pousada Portal Paraíso & 17 & 9 & $60-120$ & $\begin{array}{l}\text { Jeep, Cycling, Horse Riding, Fish- } \\
\text { ing, Boat }\end{array}$ \\
\hline I & 1997 & Fazenda Santa Tereza & 67 & 8 & $80-110$ & $\begin{array}{l}\text { Jeep, Swimming Pool, Volley Ball, } \\
\text { Horse Riding, Boat }\end{array}$ \\
\hline G & 1998 & Rio Clarinho & 46 & 8 & $60-120$ & Horse Riding, Fishing, Boat \\
\hline M & 1998 & SESC Porto Cercado & 43 & $28(60)^{1)}$ & $90-180$ & $\begin{array}{l}\text { Swimming Pool, Cycling, Children's } \\
\text { Play Ground, Horse Riding, Carriage, } \\
\text { Table Games, Movies, Fishing, Boat }\end{array}$ \\
\hline
\end{tabular}

1) Under construction

Source: Authors' field survey and Guia Quatro Rodas Brasil 2002.

owns RPPN (Reserva Particular do Patrimônio Natural) on the other side of the Cuiabá River, and controls the natural environment. From there, four fishing lodges and one eco-lodge are located in the upper stream of the Cuiabá River.

Among the accommodations in the north Pantanal, the modern hotels such as Porto Jofre Pantanal and SESC Porto Cercado provide equal or more luxurious services than the expensive hotels in state capitals. Air conditioners and satellite broadcast televisions are outfitted in the passenger compartments, and lots of benches and tables for rest are set around the large pools. Furthermore, there are amusement facilities such as card game and pool tables, movie rooms and videos that are in contrast to ecotourism.

There are also recreation facilities in the ecolodges that participate in the tourist business by reconstruction of ranch buildings, but the scale is small and the contents are simple compared with those of hotels. In the shade of big trees under the eaves of the eco-lodges, hammocks (redes) are hung so that tourists can enjoy the peace and rural atmosphere. The wild birds that are popular among tourists such as the parrot, the arara azul, and the tucanuçu (toco toucan: Ramphastos toco), are fed in the gardens.

Visitors mainly participate in package tours of four days and three nights, and join ecotours where they can stay in several different accommodations. Though the lodging fee differs depending upon the season, the average for one person in a twin room is $50-70 \mathrm{R} \$$ (reais) in eco-lodges and $80-130 \mathrm{R} \$$ in hotels, and 5-7 R \$ in the campgrounds owned by eco-lodges. Other than the room charge, when visitors participate in ecotours that are provided by the accommodation, it additionally costs $10-70 \mathrm{R} \$$ 
per tour, and there is a charge for gasoline if they use motorboats or automobiles. In comparison, the cost of the five-story hotel in front of the bus terminal of Cuiabá costs only $20 \mathrm{R} \$ \mathrm{a}$ night. The tours in the Pantanal are thus expensive. It is said that the cost of an ecotour in the Pantanal is more expensive than the cost of a stay at a coastal resort for seven days (Trent 2000).

The accommodation offer various ecotours, which are divided into types according to seasons, i.e., the inundated period (enchente) from November to January, the water-filled period (cheia) from February to April, the retreated period (vazante) from May to July, and the dry period (seca) from August to October. The amount of wildlife near to the accommodation increases during the late retreated period and the dry period, and the number of tourists and tours provided also increases as shown in Figure 5. The ecotours offered by eco-lodges are simple such as wildlife and plants sightseeing, excursion boats, and horse riding. In addition, there are various ecotours provided by modern hotels, for instance, sports fishing by motorboat, bird and animal watching tours with specialists, camping, and the "eyes of caiman tour" night cruise.

\section{Ecotourism at the Scale of Accommodation}

To present persuasive explanations for the development of ecotourism it is important to obtain detailed facts at the nodes where tourists gather, as firm evidence for future planning. In this chapter we focus on different cases of management of accommodation (nodes), using data

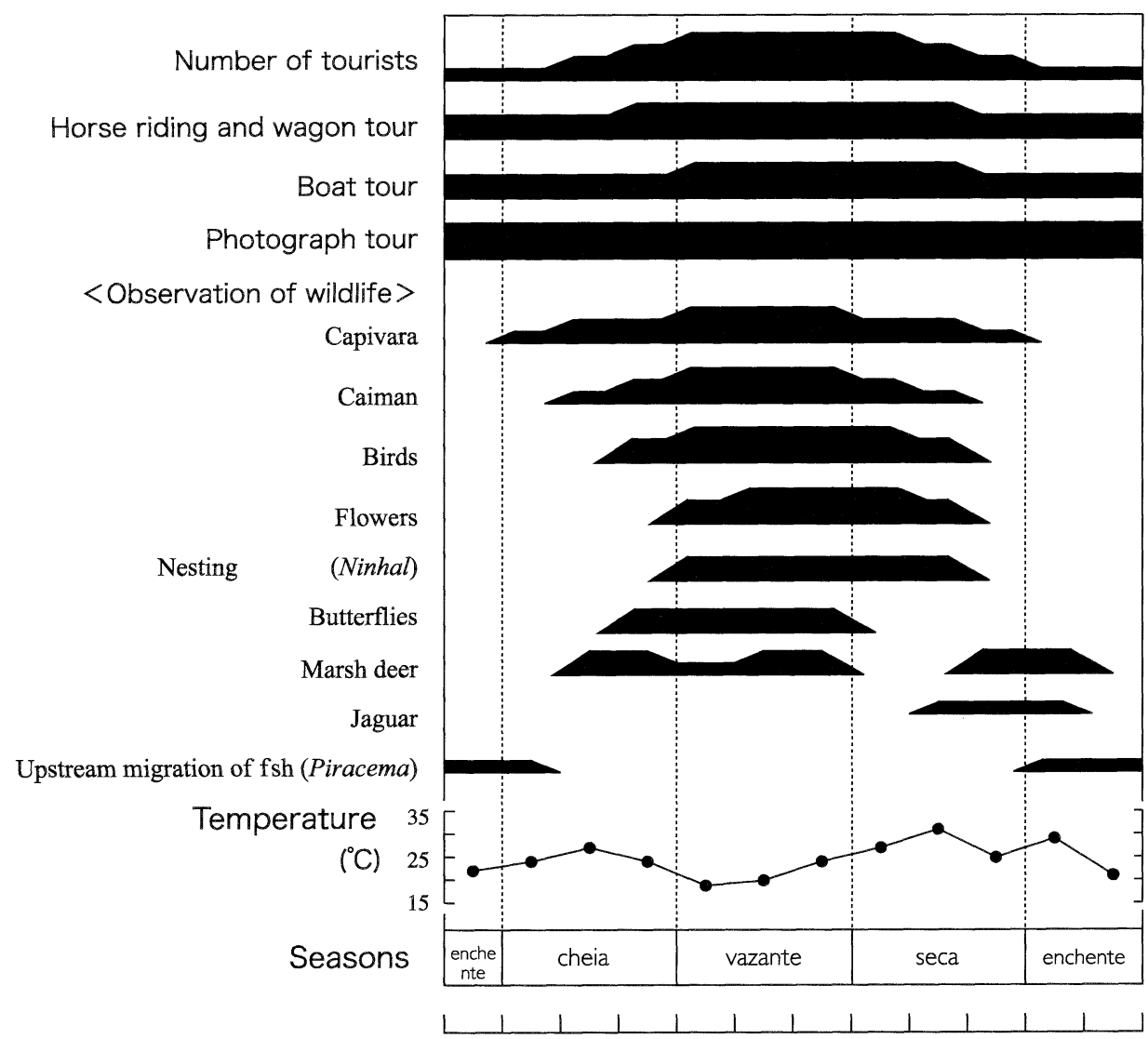

JAN FEB MAR APL MAY JUN JUL AUG SEP OCT NOV DEC

Figure 5. Seasons and ecotourism in the north Pantanal.

Source: Authors' field survey 
obtained from interviews with the landlord and officials (decision makers of nodes).

\section{Eco-lodge}

The management of the eco-lodge by the Pousada Piuval located near to the gate of Transpantaneira is described in detail in this section (Figure 4: A). Fazenda Ipiranga, with a tradition of 150 years, launched a tourism section in 1989 with the name of Pousada Piuval. ${ }^{7}$ The name is associated with the "grove of ipê (piuva)" in the ranch. In the dry season, ipê trees (Tabebuia caraiba and Tabebuia heptaphylla) are in full bloom in yellow and violet.

The building site of the eco-lodge is approximately $500 \mathrm{~m}^{2}$ (Figure 6). In inundated and water-filled periods, some parts of the site are soaked in water. The facilities for ecotourism and main building of the ranch are dispersed in the south half of the site. In the front yard of the guest houses, there are big trees such as mango and morcegueira (Andira inermis), and also benches and poles for hanging hammocks under the trees. In the yard, they also provide a swimming pool, an orchard, and a small playground for children. In the orchard, lemons, peppers, acerolas and other fruits are planted to serve in the restaurant, and chickens roam. In the courtyard of the main building, there are ranch facilities such as barns and riding grounds, and a laundry.

In the main building where the family of the eco-lodge lives, there is Guesthouse A with five rooms and a restaurant (Figure 6: a). Adjoining the main building, Guesthouse B has five rooms and Guesthouse $\mathrm{C}$ has six rooms. In the front garden of the guesthouses beside the planted cactus and flowers, there is a parabolic antenna for satellite broadcasts though there are no television sets in the rooms. Restrooms in the

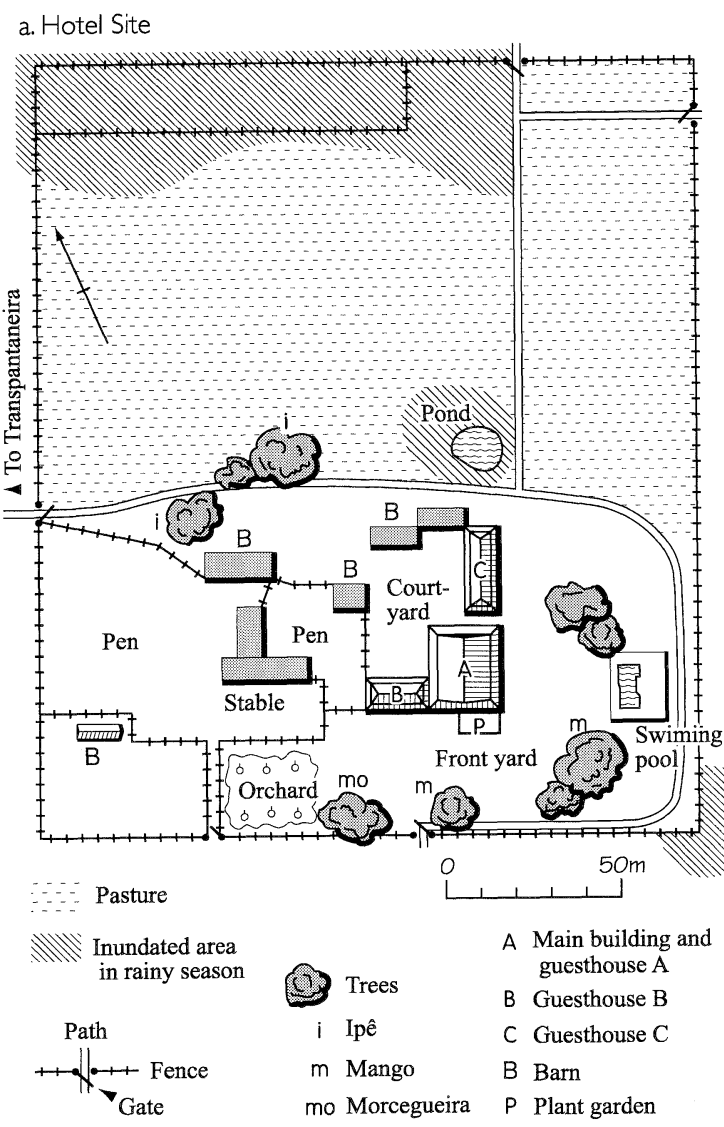

b. Main building and guesthouse $A$
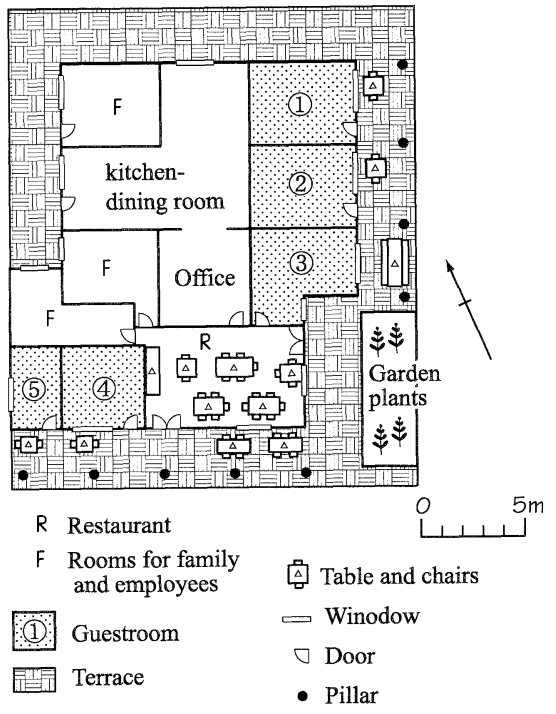

b. Guesthouse B
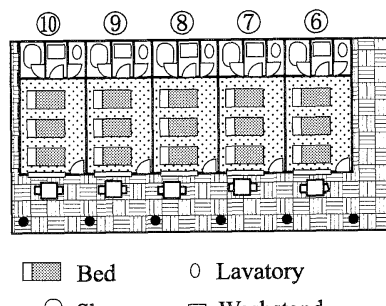

$\bigcirc$ Shower $\square$ Washstand

Figure 6. Plan of Pousada Piuval, 2001.

Source: Authors' field survey 
guesthouse have flush toilets, and the showers and baths use cold water. Chairs and tables are placed at the front of each room, and hooks for hanging hammocks are nailed on the pillars of the eaves. The eco-lodge feeds an arara azul and its toddling movements in front of the guesthouses catch the eyes of tourists.

This eco-lodge is run by family management. The master is 56 years old, and his wife and daughter are in charge of the tourism. The guesthouses are graded as eleven first-class rooms (Figure 6: a and c) and five second-class rooms. The capacity of the total bedrooms is 50 people. This is the same capacity as the number of seats of a large sightseeing bus. However, at the time of carnival, the busiest season, five people stay in each room. The cost of a firstclass room is $80 \mathrm{R} \$$ for a single room, $140 \mathrm{R} \$$ for a twin room, and $220 \mathrm{R} \$$ for a quadruple room. The main ecotours they provide are wildlife and landscape sightseeing by means of horseback riding and rowing boat, and it costs $20 \mathrm{R} \$$ per day.

The main customers of the eco-lodge from January to March are Brazilian. They are especially concentrated in late February and March when large festivals such as the celebration of the carnival and the Semana Santa take place. However, 90 percent of customers during the dry period of July and August are foreigners, and a few Brazilians come for weekends. The foreign customers are mainly German, as well as a number of Italians, English, French, and Portuguese.

Since this eco-lodge also manages stockfarming, there are traditional ranch facilities such as wooden fences, pens, and barns for livestock production adjoining the accommodation facilities. There are 1500 cattle, 110 horses, and six donkeys. The cattle are the breeding cattle that produce calves to be shipped and fattened outside of the region. This eco-lodge owns no less than 7000 ha of land. However, it is relatively small compared with the fazendas around the eco-lodge holding 32 to 72 thousand ha.

\section{Hotel}

Facilities for lodging As a case of ecotour management in a hotel equipped with modern facilities, we will look at the case of SESC Porto Cercado. It is a new hotel established in 1998 with $4000 \mathrm{~m}^{2}$ of building lot (Figure 7). The property of the hotel extends to 106 thousand ha in the municipalities of Poconé and Barão de Melgaço.

Facing the Cuiabá River, there are wharves on the south site of the hotel, and four buildings for lodging and recreation. At the guest house in the western part of the hotel site, there are six suite rooms on the upper stories (Figure 7: Gs). The numbers of rooms and the capacity of rooms were 34 and 100 in 2000, and they will increase to 60 and 160 , respectively. ${ }^{8}$ In the center of the corridor that connects the guest houses and the restaurant, there is a front desk, an office, and a souvenir shop in which they sell t-shirts and hats of the brand of SESC Porto Cercado (Figure 7: Fo and Sv). There are 16 employees on the front desk, 45 for other facilities in the hotel, and 15 for the office in Cuiabá. Many of them live in Poconé and commute by car to the hotel, taking an hour to travel a distance of $40 \mathrm{~km}$.

The restaurant is one of the largest buildings in the hotel, and the meals are sumptuous. The buffet-style dinner includes more than 20 dishes, and feijoada (black-bean stew boiled together with pork giblets) is served every day. To the north of the restaurant, there is a power plant and a food storage facility with a large cold store (Figure 7: $\mathrm{P}, \mathrm{Sg}$ ). In the storage facility, besides perishable meat and fruit, there is space for the goods sold at the souvenir shops and office supplies such as fluorescent lamps and packaging tapes. Fresh food is ordered on Friday and arrives on Monday from Cuiabá.

In the northwest part of the property of the hotel, Fazenda Baía das Pedras was established in December of 2001 (Figure 8). The sightseeing ranch owned by SESC Porto Cercado is aimed at providing various services to the tourists staying at the hotel. There are no guesthouses but stables, a barbecue cottage (churrasqueira), horseback riding courses, and a compost plant. The stables are sealed to prevent horses becoming lean during the rainy season (December to February) due to the upsurge of mosquitoes, and are equipped with a medical office for veterinary doctors. There are 


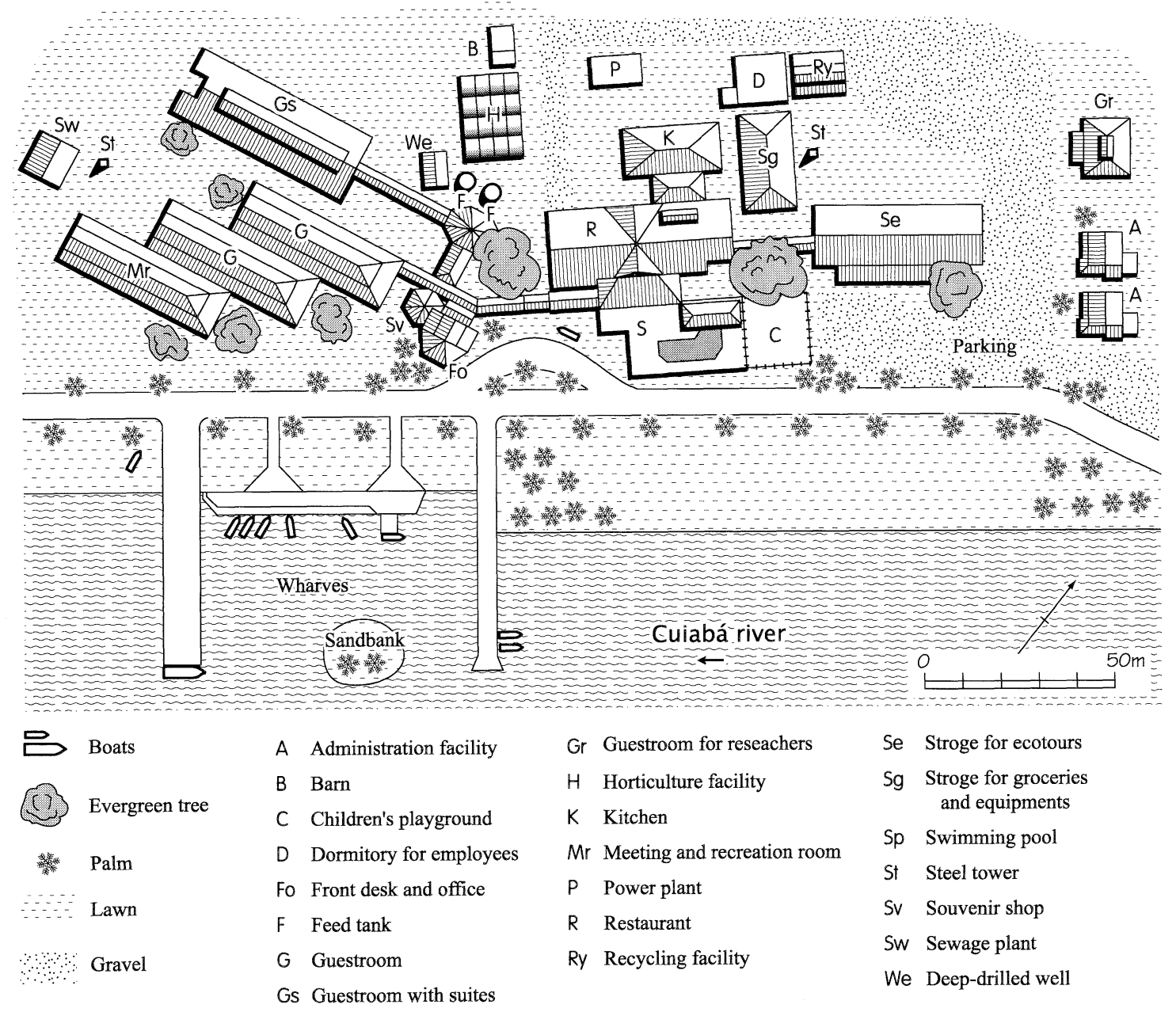

Figure 7. Plan of SESC Porto Cercado, 2001. Source: Authors' field survey

presently 11 horses though this will be increased to 30 or 40 before long. There is an intermittent river (corixo) called the Corixão adjacent to the ranch. Though it becomes three to four meters deep in inundated and waterfilled periods, puddles are left after the subsidence of water during the dry period. Along the river bank, beautiful trees grow naturally such as the ipê, and the paineira (of the Bombacaceae family). ${ }^{9}$

Year-round ecotours SESC Porto Cercado adopts two types of room charges depending upon on the season and day of the week. A high price list is used from July to September, and on Saturdays and Sundays in other months. The room charges for one person are respectively 138 and $110 \mathrm{R} \$$ for a single room, 104 and 84
$\mathrm{R} \$$ for a twin room, and 92 and $74 \mathrm{R} \$$ for a triple room. The SESC group takes a member system and they manage many hotels in Brazil. Members of the SESC receive a discount and can stay there for half the price.

Owing to the membership system in Brazil, SESC Porto Cercado receives customers mainly from domestic states. The number of lodging customers in the hotel from 2000 September to 2001 July is shown in Table 2 . It shows that 4956 people (95\%) out of 5184 in total are domestic customers. Many of the domestic customers came from the local state of Mato Grosso (3052 people) and also the neighboring state of São Paulo (918). Seasonally, the number of lodging customers increases and the distance from which customers come extends in 


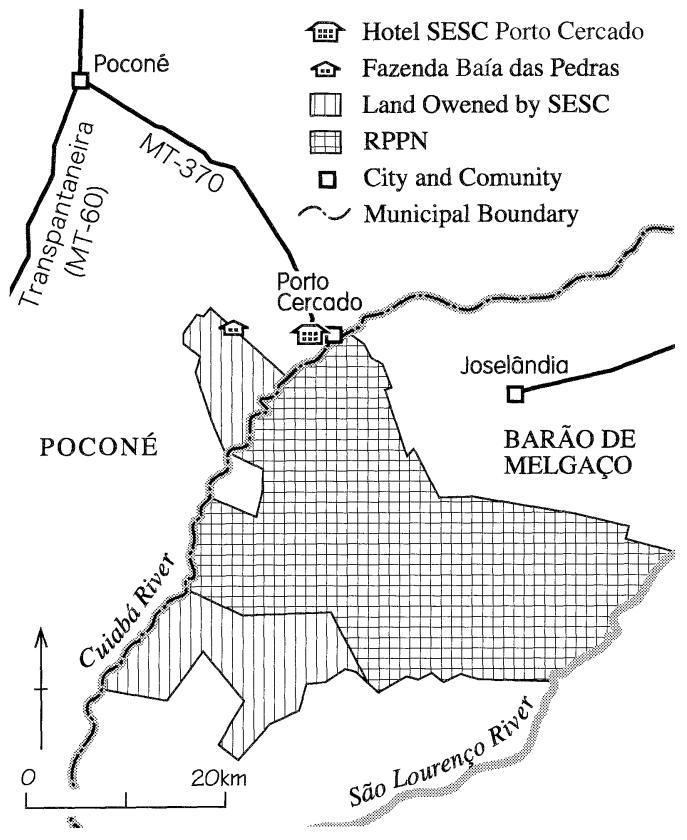

Figure 8. Estate of SESC Porto Cercado, 2001. Source: SESC Porto Cercado

the retreated and dry periods of July to September, and also during the inundated period of December to February. At weekends, the number of lodging customers increases from local cities such as Cuiabá and Poconé. Paying attention to the nationality of the lodging customers from abroad, main countries are listed as Portugal (102 people), the United States of America (42), Germany (24) and Uruguay (10). The number of foreign customers increases from the late of dry period to the inundated period. To appeal to foreign customers, SESC Porto Cercado holds exhibitions of the Pantanal in European cities such as Berlin and Roma. Whether or not this is a factor, it has a great number of customers every month, more than 600 people during the highest month (July) and about 300 people even during the lowest month (June).

In order to respond to the lodging customers who visit all year-round, SESC Porto Cercado offers various excursions (Table 3). The ecotours and recreations conducted by guides are performed 12 times a day from 8 a.m. to 9 p.m. The contents are changed by day of the week and season. The main tours practiced year-round are sightseeing by boat, sportsfishing boats, horse riding, carriage trips and photographic tours. In addition to these tours, observation and study tours of caimans, capivaras, deer, wild-birds, butterflies, and flowers are available during the dry and retreated periods. In other periods, amusements such as barbecues (churrasco) and movie shows are popular.

Facilities for environmental consideration The efforts for environmental consideration and social contributions practiced by SESC Porto Cercado will be explained next by the cases of RPPN and recycling. RPPN is the land preserved for researching and conservation of the tropical forest, which is exempt from taxation in place of development. The total area of RPPN in the north Pantanal amounts to 171,972 ha (Table 4). The RPPN named Estância Ecológica SESC Pantanal extends to 87,871 ha between the Cuiabá River and the São Lourenço River that streams about $20 \mathrm{~km}$ southeast of the hotel (Figure 8). The preserved land was designated in 1997, and an observation tower of $39 \mathrm{~m}$ and a study hut for field studies were constructed. ${ }^{10}$ The guesthouse in the east part of the hotel site is used as the base for the researchers who conduct long-term field studies (Figure 7: Gr). The facility is utilized mainly by the federal university of Mato Grosso. The lodging customers of SESC Porto Cercado are not only ecotourists but also domestic and foreign researchers and students.

Garbage disposed from the hotel is separated into 7 types in the recycling facility (Figure 7 : Ry). Empty bottles are washed in the facility and shipped to Poconé to be sold. Dry cells and glassware are also shipped to Poconé and disposed of in the town. Organic trash such as leftover food is kept temporarily in the cold storage of the recycling facility in order not to decay. It is carried to Baía das Pedras and stocked for 120 days, mixed with grasses, manure, and the soil of Cerrado. It is made into compost and is reused as fertilizer for horticulture and garden soil. In the horticulture facility, which is encircled by insect proof nets $(\mathrm{H})$, they produce crops that are consumed in the restaurant such as vegetables, fruits, herbs and spices. ${ }^{11}$ In the barn adjoined to the horticulture facility, the seeds of plants such as the Sansão do Campo, which grows three meters in 
Table 2. Visitors to SESC Porto Cercado

(person)

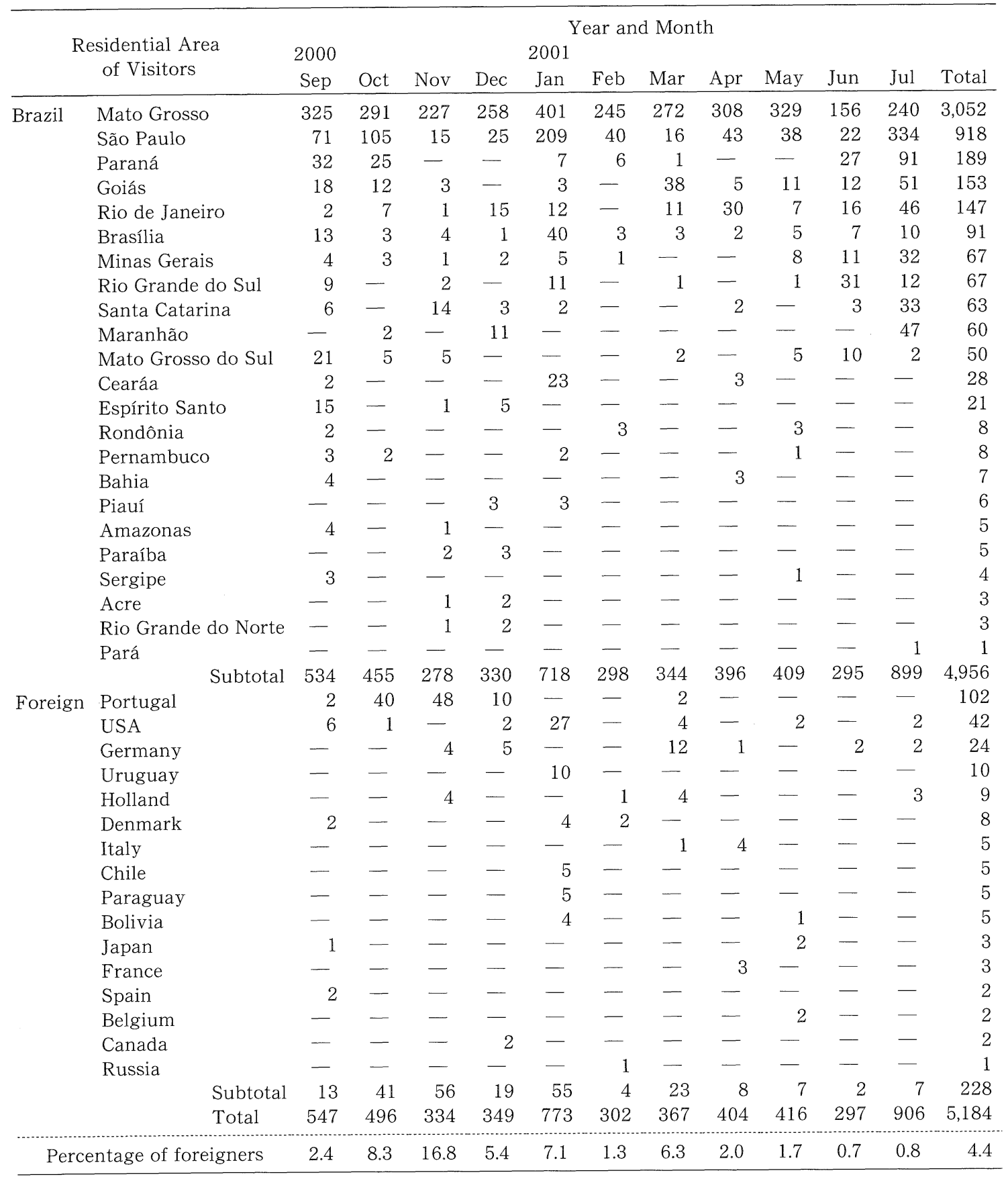

Source: SESC Porto Cercado 


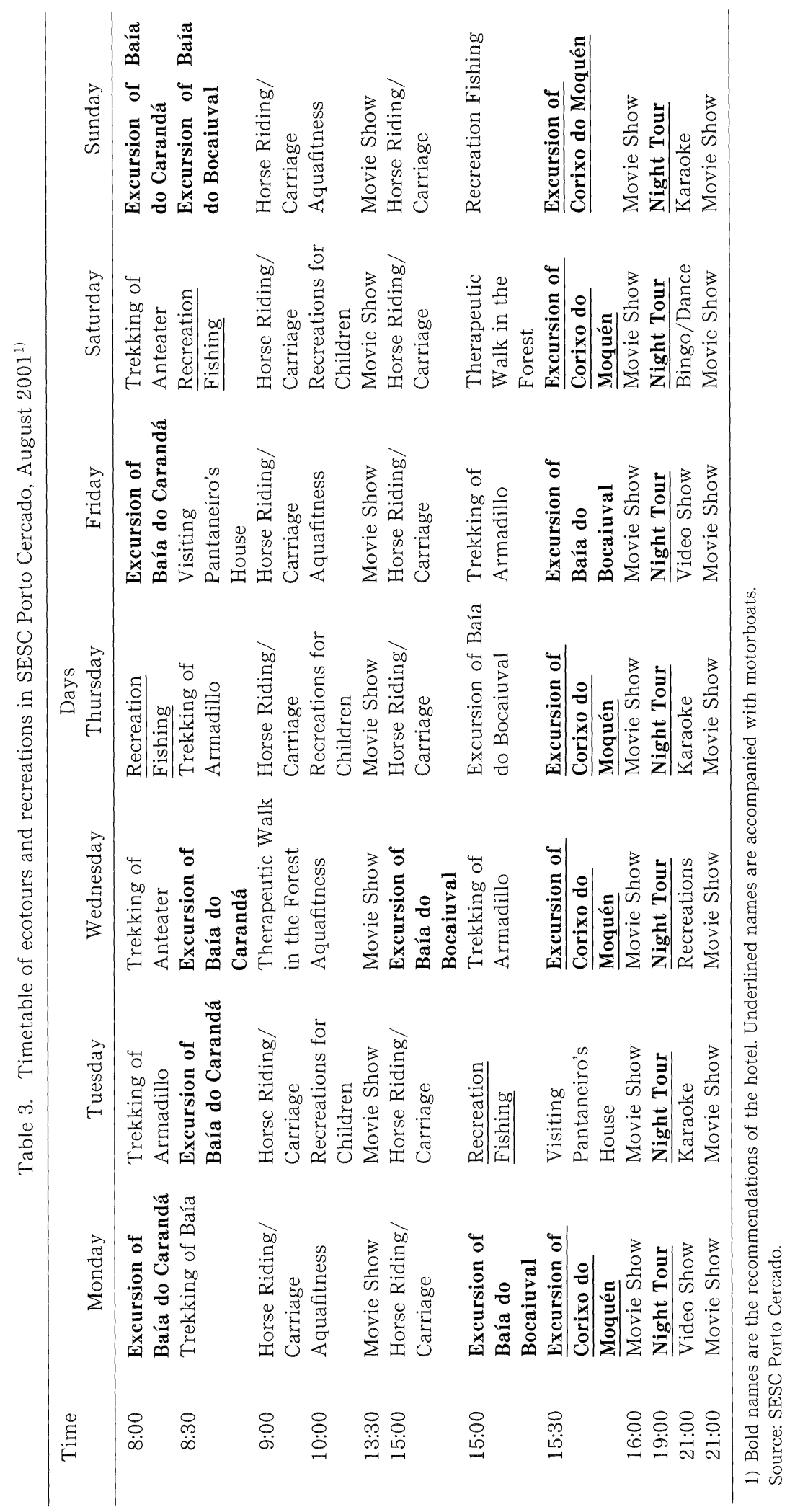


Table 4. Area of RPPN (Reserva Particular do Patrimônio Natural) in the north Pantanal, 2003

\begin{tabular}{llr}
\multicolumn{1}{c}{ RPPN } & \multicolumn{1}{c}{ Municipal } & Area (ha) \\
\hline Estância Ecológica SESC Pantanal & Barão do Melgaço & $87,871.44$ \\
Reserva Jubran & Cáceres & $35,531.00$ \\
Estância Dorochê & Poconé & $26,531.00$ \\
Reserva Ecológica Verde Amazônia & Apiacás & $10,605.67$ \\
Reserva Ecológica América Amazônica & Apiacás & $4,943.00$ \\
Parque Ecológico João Basso & Rondonópolis & $3,624.57$ \\
Reserva Ecológica da Mata Fria & Chapada dos Guimarães & 995.00 \\
Reserva Ecológica Lourdes Félix Soares & Nova Canaã & 800.00 \\
Floresta Amazônica Hotel & Alta Floresta & 670.00 \\
Fazenda São Luiz & Cuiabá & 200.00 \\
José Guimarães Soares & Nova Canaã & 200.00 \\
Total & & $171,971.68$ \\
\hline
\end{tabular}

Source: Agência Brasileira de Meio Ambiente e Tecnologia da Informação.

a year, are stocked to maintain the greens in the hotel. Water is pumped up from a deep well of $106 \mathrm{~m}(\mathrm{We})$, and is used in the hotel after it is filtered and treated with chemicals. The sewage is cleaned by decantation and filtering in the sewage plant $(\mathrm{Sw})$ and poured into the river. To save water resources bath and hand towels in the rooms are exchanged only when customers demand washing service.

\section{Structure of Regional Bases}

Referring to the results mentioned in the previous chapters, we focus on the elements that can be regarded as the bases of regional ecotourism in the north Pantanal. The structure of regional bases could be described in a simple way in order of regional scale as shown in Figure 9. In our discussion on the future development of the region, some elements that

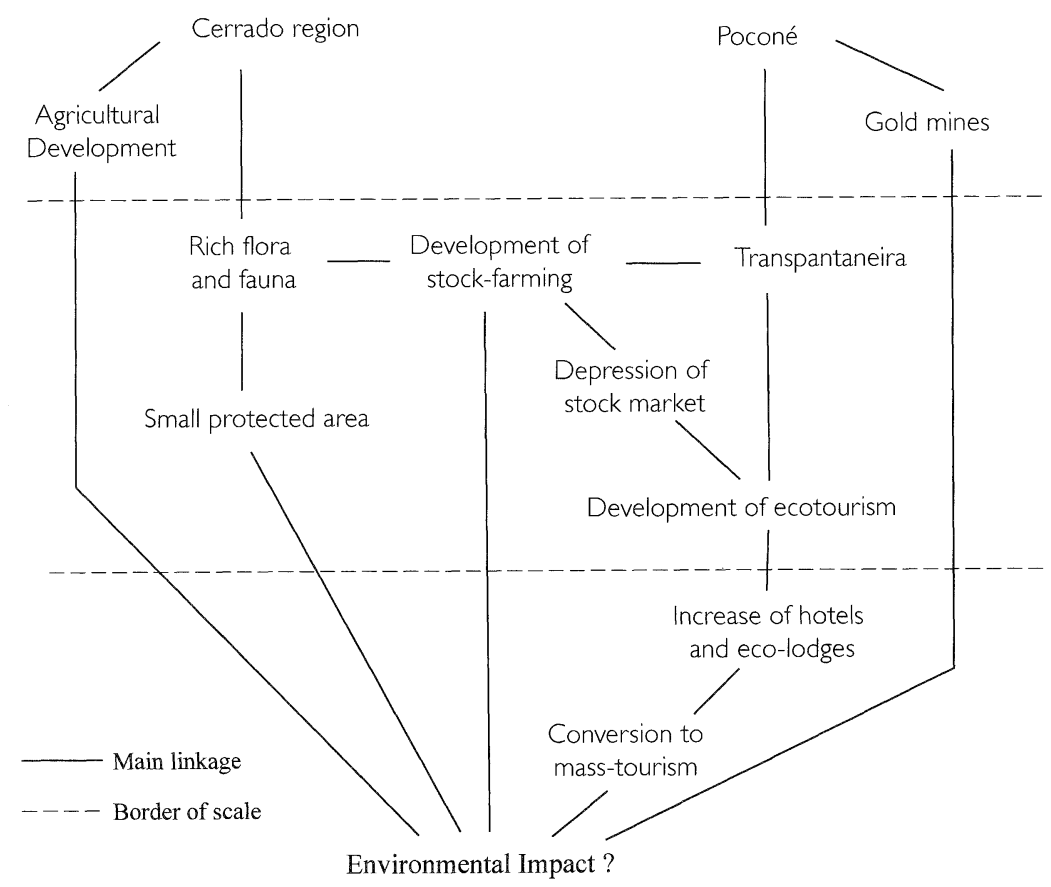

Figure 9. A model of the structure of regional bases for ecotourism in the north Pantanal. 
would bring environmental impact are the focus of this chapter, i.e., (1) development of cropland and gold mines in the periphery of the wetland, (2) environmentally protected area and Transpantaneira in the wetland, and (3) the ecotourism in hotels and eco-lodges.

\section{Development around the wetland}

The rich flora and fauna that sustain ecotourism in the wetland depend much on natural phenomena, especially the influx and efflux of water on the plains caused by water level fluctuation of the big rivers crossing from northeast to southwest, such as the Cuiabá, São Lourenço and Piquiri Rivers. The rivers' water sources are located in the Cerrado region in the east of the north Pantanal. On the plateaus in the region, e.g., Serra de São Jerônimo and the Brazilian Highlands, agricultural development has recently become prosperous. In particular, the arable lands composed mainly of the production of soybeans and cotton are spreading along the thoroughfares between Rondonópolis and Coxim. The agricultural development of the surrounding area would lead to serious environmental problems in the wetland, such as the accumulation of soil in the riverbeds, destruction of corridor forests (mata ciliar), fluctuation of watercourses, and water contamination, because of soil erosion from open-field and the increased usage of agricultural chemicals.

In the gold mines of Poconé, it is presumed that 10-15 tons of mercury was used to produce amalgam in the 1980s (Lacerda et al. 1991). Some quantity of this mercury flows and evaporates into the rivers and the atmosphere increases at the start of the rainy season. On average, the quantity of the mercury in the atmosphere of the season amounts to $5.3 \mathrm{ng} / \mathrm{m}^{3}$ in the built-up area of Poconé, and $2.8 \mathrm{ng} / \mathrm{m}^{3}$ in the wetland located $100 \mathrm{~km}$ downstream from the town (Von Tümpling et al. 1995). The values were about 2.7 to 1.4 times larger than those of the Serra das Araras located in the northern part of the state. A study also reports that fertile women should avoid eating the piscivorous fish caught in the Cuiabá River during the dry season (Hylander et al. 2000). Planning and execution of effective measures for the gold mines on the outskirts of Poconé should be worked out urgently since strip mining has resulted in serious direct damage to the ecosystem of the wetland through deforestation, erosion, the accumulation of soil, and mercury contamination.

\section{Protected area and Transpantaneira}

The north Pantanal is an important region for the ecotourism of Brazil for its environmental diversity and economic development. However, the area protected as a national park is diminutive as compared with the huge extent of wetland. The national park is located deep in the wetland, about $50 \mathrm{~km}$ southwest of Porto Jofre (Figure 2), and the area was designated much later than the other large national parks in the country. One of the reasons that keep the small protected area from expanding is that the large part of the wetland is occupied by the estates of private ranches. Seidl et al. (2001) estimated about $95 \%$ of the area of the Brazilian Pantanal is private property, and $80 \%$ of the area is classified as extensive pasturage. Economic equilibrium in the development of stock farming needs to be considered, however, the recent prosperity of ecotourism, expanding into natural conservation areas such as national parks and RPPN will bring a large economic profit to owners of the wetland in the north Pantanal.

Transpantaneira had been built to promote stock farming in wetland but its main role was changed to the transportation of tourists during the stock market depression in the 1980s. It accelerated the development of ecotourism, i.e., an increase in the number of tourists and infrastructure such as hotels, eco-lodges, and parkroads. The increase of tourists has simultaneously impacted on the regional environment. During ecotours in the region, tourists will see carcasses of animals run over by automobiles and the plastic bottles thrown away on the park-roads and riverbanks. Though the hunting and gathering of animals and plants are prohibited on the park-roads and also in the wetland, it is difficult to exercise strict control over the deforestation and poaching by land managers and the thoughtless behavior of visitors. $^{12}$ 


\section{Hotels and eco-lodges}

Many of the accommodations are the ecolodges that were converted from ranches (fazenda). Small eco-lodges depend much on urban travel agencies in that they rely on the press and brochures for tourists, despite the fact that knowledge of the people who live in the region is a resource of ecotourism. In such eco-lodges, there is also the problem that due to shortage of funds they are lagging behind in facilities for environmental preservation such as sewage and waste disposal plants. Codes for ecotourism, by which visitors receive the benefit of nature in the unhurried atmosphere of the north Pantanal are needed. The initiative in practicing systematic ecotours should be taken by the local people and the instructors who are well acquainted with regional nature.

The large hotels equipped with modern facilities prepare many services, and some of them tend to become merely holiday resorts. The knowledge and understanding of regional environment among the guests and hosts seems insufficient, and, in addition, systematic ecotours are not offered sufficiently. The amusement events they provide, in particular, seem to be assimilated into mass-tourism. Some of the ecotourism provided by them seem not to aim at conserving the natural environment but to take pleasure in it. The tendency involves the possibility of conversion to mass-tourism. However, though it is still in development and holds problems, some hotels are also looking to develop study tours to teach the ecosystem of the wetland.

\section{Conclusion}

Most of the ecotours in the Pantanal include the observation of natural resources and sports fishing. The success of ecotourism is essentially due to the abundant wildlife and plants of the wetland. The observational study of the Pantanal is important in the sense that it contributes to our understanding of the importance of the tropical wetland, which is regarded as a valuable property for people now and in generations to come. This study examined regional bases to sustain the ecotourism of the wetland from the case of the north Pantanal. The results also will provide some proposals for the development in the region in future.

By examining the regional bases of ecotourism that are arranged in order of regional scale, our summaries are given as follows. (1) In the surrounding area of the wetland, it is necessary to make efficient plans to control recent agricultural development especially in the Cerrado region, one of the water sources of the north Pantanal. Environmental subsidies are needed for disused goldmines around the wetland. (2) On the wetland level, legally protected area such as national park and RPPN should be extended, and plans for the maintenance and ecological use of the infrastructures such as Transpantaneira and MT370 should be practiced. (3) Modern hotels and eco-lodges need to provide ecotourism organized by local people, and to prepare facilities with adequate sewage facilities and recycle plants to preserve the natural environment.

The administration is dealing with such problems by drawing up a plan named the "Pantanal Project" whose aims are to promote preservation of the environment and sustainable development. However, it is difficult to understand and to perform the ethical standards necessary for compatibility between the environment and the sightseeing business. It will be accompanied with the burden of cost of environment preservation facilities especially on the managements in small lodges. In order to cope with the dilemma involved in ecotourism, i.e., economic development of tourism and the sustainable usage of regional resources, local residents, travel agents in city and tourists should recognize the "wise use" of the wetland ecosystem (Davis 1993). The people of the region should devise the system of eco-tourism that provides a "tourism of thinking" to visitors from outside.

\section{Acknowledgements}

We express our sincere gratitude to $\mathrm{Mr}$. Shojiro Saeki in Linkbrazil, Mr. Marcelo T. C. de Oliveira in IPÁ TI-UÁ (Environmental NGO), Ms. Maria Esther and Mr. Edson Messias de Almeida in Fazenda Baía Bonita. This study is supported by Japan Society for the Promotion of Science (JSPS Grant-in-Aid for Scientific Research B(2) No. 16401023, fiscal year 2004- 
2006).

(Received 3 February 2004)

(Accepted 1 December 2004)

\section{Notes}

1. Sustainable development must follow moderate development that takes into account the demands of the current and future generations (Gibbon et al. 1995).

2. There are 47 national parks, totaling up to 10.4 million ha, in Brazil. The national parks are controlled and preserved by IBAMA (Instituto Brasileiro do Meio Ambiente e dos Recursos Naturais Renováveis). The largest national parks are Jaú (2.3 million ha), Pico da Neblina (2.2) and Amazonia (1.0). The top three national parks are located in the basin of the Amazon River, and they were designated as national parks in 1980, 1979 and 1974, respectively. The oldest national parks of Brazil are Itatiaia (30 thousand ha) and Iguaçu (185), which were designated in 1937 and 1939, respectively.

3. The vegetation of Cerrado is also observed in the wetland.

4. In 1979, the junta period of Brazil, the state of Mato Grosso was separated into Mato Grosso (capital: Cuiabá) and Mato Grosso do Sul (Campo Grande). At the same time, the Brazilian Pantanal was split into north and south administratively. The Piquiri and the Cuiabá Rivers in the Pantanal form the boundary between the two states, and the north Pantanal belongs to Mato Grosso.

5. The largest fish caught was during the 1999 competition, which was a surubim that attained 1.32 meter in length and weighed 35 kilograms. In the main competition, blunt fishhooks are used in order not to damage the fish, and all fish caught are released back into the river after having been measured.

6. Though opinions on the number of bridges along Transpantaneira are divided, the authors' observation using GPS in August 2001 resulted in 118 bridges between the gate and Porto Jofre. Among them, 116 are wooden bridges and two are made of concrete.

7. Professors Machias and Kach in UFMT (Universidade Federal de Mato Grosso) who carried "Projeto Gran Pantanal" surveyed 50 wells in the north Pantanal. Among the samples, 20 were located in Fazenda Ipiranga. Guimarães et al. (1998) also conduct surveys of mercury methylation in the Fazenda. Their results show that the speed (intensity) of methylation is nine times faster in the route of hydrophytes than that of the sediment.

8. Data is obtained from interviews with $\mathrm{Mr}$.
Vinicious, the vice manager (subgerente) of SESC Porto Cercado, and with Mr. Marcus in charge of technological service (serviço de assistência técnica) on 17 th and 18th August in 2001.

9. Paineira bears seeds with abundant white fluff. They are available to fill pillows and outfits for cold weather. It can flare up by accidentally touching with a naked flame.

10. Their subjects relate generally to ethology, herpetology, planktology, taxonomy, plant geography, vegetation dynamics, hydrology, soil science, geomorphology, and the density of inhabitants, territory, distribution, renovation and regeneration of animals and plants.

11. The crops are: manjericão (basil), soja (soy bean), hortelã (mint), couve (Brussels sprout), alface (lettuce), mostarda (mustard), chicória (chicory), rabanete (radish), agrião (watercress), cebolinha (spring onion), pimentão (green pepper), pepino (cucumber), quiabo (gumbo), berinjela (eggplant), etc.

12. To give an example of the caiman, one million skins were poached illegally every year in the 1970s and 1980s (Mourão et al. 2000).

\section{References}

Bordest, S. M. L., Macedo, M., and Priante, J. C. R. 1996. Potencialidades e limitações do turismo na Bacia do Alto Paraguai, em Mato Grosso. In Resumos: II Simposio sobre recursos naturais e socioeconomicos do Pantanal, ed. E. K. Resende, E. C. Moretti, I. M. Bortolotto, G. M. Mourao, J. M. F. Loureiro, M. E. B. Oliveira, M. Dantas, M. Santomo and S. A. Santos, 503-506. Brasilia: EMBRAPA-SPI. (P)

Britski, H. A., Silimon, K. Z. de S. de and Lopes, B. S. 1999. Peixes do Pantanal: Manual de identificação. Corumbá: EMBRAPA-CPAP. (P)

Burton, F. 1998. Can ecotourism objectives be achieved? Annals of Tourism Research 25: 755758.

Ceballos-Lascurain, H. 1987. The future of ecotourism. Mexico Journal January: 13-14.

Ceballos-Lascurain, H. 1996. Tourism, ecotourism, and protected areas: the state of nature-based tourism around the world and guidelines for its development. Gland, Switzerland: IUCN.

Davis, T. G. ed. 1993. Towards the wise use of wetlands: Report of the ramsar convention wise use project. Gland, Switzerland: Ramsar Convention Bureaul.

Duffy, R. 2002. A trip too far: ecotourism, politics and exploitation. London: Earthscan.

Fennell, D. A. 1999. Ecotourism: An introduction. London and New York: Routledge.

Foucat, V. S. A. 2002. Community-based ecotourism management moving towards sustainability in Ventanilla, Oaxaca, Mexico. Ocean \& Coastal Management 45: 511-529. 
Funck, C. 2002. Is ecotourism sustainable? Geographical Sciences 57: 158-167. (J)

Gibbon D., Lake, A. and Stocking, M. 1995. Sustainable development: a challenge for agriculture. In People and environment, ed. S. Morse and M. Stocking, 31-68. London: UCL Press.

Guimarães, J. R. D., Meili, M., Malm O. and Brito, E. M. S. 1998. Hg methylation in sediments and floating meadows of a tropical lake in the Pantanal floodplain, Brazil. The Science of the Total Environment 213(1-3): 165-175.

Hylander, L. D., Pinto, F. N., Guimarães, J. R. D., Meili, M., Oliveira, L. J. and Silva, E. C. 2000. Fish mercury concentration in the Alto Pantanal, Brazil: influence of season and water parameters. The Science of the Total Environment 261(1-3): 9-20.

Ishimori, S. 2001. Endogenous tourism-development and autonomous tourism. Senri Ethnological Reports 21: 5-19. (JE)

Japan Ecotourism Society 1999. Entering the ecotourism age. Tokyo: Japan Ecotourism Society. (J)

Lacerda, L. D., Pfeiffer, W. C., Marins, R. V., Rodrigues, S., Souza, C. M. M. and Bastos, W. 1991. Mercury disposal in water, sediments and aquatic biota of gold mining tailings drainage in Poconé, Brazil. Water Air Soil Pollution 56: 785-796.

Lindberg, K., and Hawkins, D. E. eds. 1993. Ecotourism: A guide for planners and managers. Bennington: The Ecotourism Society.

Ministério do Meio Ambiente, dos Recursos Hídricos e da Amazônia Legal 1997. Plano de conservação da bacia do alto Paraguai. Brasilia: PCBAP-PNMA. (P)

Mourão, G., Coutinho, M., Mauro, R., Campos, Z., Tomás, W. and Magnusson W. 2000. Aerial surveys of caiman, marsh deer and pampas deer in the Pantanal Wetland of Brazil. Biological Conservation 92: 175-183.

Nakasumi, T. 1990. The Pantanal. Mumyousha: Akita. (J)

Nihei, T. 2003. Ecotourism: Kankougyou no hatten to bashotokusei no henka (Ecotourism: development of tourism and changes in the significance of place). Chiri (Geography) 48(12): 30-37. (J)
Ross, S. and Wall, G. 1999. Ecotourism: towards congruence between theory and practice. Tourism Management 20: 123-132.

SEDTUR 2001. Mato Grosso: Quatro Estações, quatro regiões, mil emoções! Cuiabá: SEDTUR (Secretaria de Desenvolvimento do Turismo do Estado de Mato Grosso). (P)

Seidl, A. F., Silva, J. S. V. and Moraes, A. S. 2001. Cattle ranching and deforestation in the Brazilian Pantanal. Ecological Economics 36: 413-425.

Sendai, Y. 2001. Estudio del impacto de desarrollo turístico en la Amazonía Ecuatoriana: El caso de la sociedad de los huaorani. Senri Ethnological Reports 23: 199-210. (JS)

Swarts, F. A. 2000. The Pantanal in the 21st century: For the planet's largest wetland, an uncertain future. In The Pantanal: Understanding and preserving the world's largest wetland, ed. F. A. Swarts, 1-22. St. Paul, Minnesota: Paragon House.

The International Ecotourism Society 2000. Ecotourism statistical fact sheet. Washington, DC: The International Ecotourism Society.

Trent, D. 2000. Ecotourism in the Pantanal and its role as a viable economic incentive for conservation. In The Pantanal: Understanding and preserving the world's largest wetland, ed. F. A. Swarts, 107-115. St. Paul, Minnesota: Paragon House.

Von Tümpling Jr., W., Wilken, R. D. and Einax, J. 1995. Mercury contamination in the northern Pantanal region Mato Grosso, Brazil. Journal of Geochemical Exploration 52: 127-134.

Wallace, G. N. and Pierce, S. M. 1996. An evaluation of ecotourism in Amazonas, Brazil. Annals of Tourism Research 23: 843-873.

Weaver, D. B. 1998. Ecotourism in the less developed world. New York: CAB International.

Weaver, D. B. 1999. Magnitude of ecotourism in Costa Rica and Kenya. Annals of Tourism Research 26: 792-816.

$(\mathrm{J})$ : written in Japanese

(JS): written in Japanese with Spanish abstract

(P): written in Portuguese 